\title{
sciendo
}

\author{
ALINA DZIRBA, MARIUSZ GONIEWICZ, PATRYCJA MISZTAL-OKOŃSKA
}

\section{Safety of intramuscular injections in medical rescue}

\begin{abstract}
Injection is the delivery of medication into the tissues. It is the administration of medication by means of a needle (cannula) into the body tissues, cavities or blood vessels. An injection is one of aseptic procedures, i.e. those that require the use of sterile equipment, sterile medication, and treatment in compliance with the principles of asepsis. Failure to observe these rules as well as those that have to be followed in connection with the delivery of medication regardless of the route of administration may result in many complications. The administration of medications by paramedics is one of their competencies defined in the Regulation of Health Minister of 20 April 2016 on the medical emergency treatment and health services other than medical emergency treatment that can be provided by a paramedic. A paramedic can himself administer 47 drugs specified in the foregoing Regulation, and he can also administer other drugs as ordered by a doctor. The article describes the principles of safe intramuscular injection as one of the methods of administering medication in emergency medicine.
\end{abstract}

Keywords: intramuscular injection, technique of selecting the puncture site, injection, emergency medicine, nursing, place of injection.

DOI: $10.2478 /$ pjph-2018-0026

\section{INTRODUCTION}

Injection is the delivery of medication into the tissues. It is the administration of medication by means of a needle (cannula) into the body tissues, cavities or blood vessels. An injection is one of aseptic procedures, i.e. those that require the use of sterile equipment, sterile medication, and treatment in compliance with the principles of asepsis. Failure to observe these rules as well as those that have to be followed in connection with the delivery of medication regardless of the route of administration may result in many complications.

The administration of medications by paramedics is one of their competencies defined in the Regulation of Health Minister of 20 April 2016 on the medical emergency treatment and health services other than medical emergency treatment that can be provided by a paramedic [1-2].

A paramedic can himself administer 47 drugs specified in the foregoing Regulation, and he can also administer other drugs as ordered by a doctor. Drugs used in medical emergency services have different forms (pill, aerosol for sublingual administration, nebulization suspension, intrarectal infusion, suppository, gel, gas, injection solution, solution for intravenous infusion) and different routes of delivery. The following routes of medication administration have been distinguished:

Enteral routes, via the alimentary canal:

- oral - per os (p.o.)

- intrarectal - per rectum (p.r.)

- $\quad$ sublingual - sublingue (s.l.)
Parenteral routes, extraintestinal:

- subcutaneous - subcutanea (s.c.)

- intramuscular - intramuscularis (i.m.)

- intravenous - intravenosa (i.v.)

- intraosseous - intraosseous (i.o.)

- via the respiratory tract - by inhalation, in nebulization, or, exceptionally - through endotracheal tubes

Apart from intravenous injections, intramuscular injections are a frequent treatment procedure carried out by paramedics. The correct carrying out of a procedure is a condition for the safe provision of assistance to patients and for the protection of them from complications following the intramuscular administration of the drug.

Although the deltoid muscle, the quadriceps femoris, the gluteus muscle on the abdominal or on dorsal side can be chosen for intramuscular injection, it should be remembered that the best conditions for drug absorption are in a well-developed large-mass muscle, well blood-supplied, distant from larger blood vessels and nerves. The muscle that satisfies the foregoing conditions is the gluteus muscle on the dorsal side, which was previously used for intramuscular injections as a standard. The site of needle insertion was located on the basis of the socalled quadrant method [3-12].

In the early twenty-first century in literature there emerged criticism of the use of gluteus muscles on the dorsal side for intramuscular injections (Nikolaus Hildebrand). The justification for criticism was the argument that in the quadrant method the location of the site of needle insertion has no relation to the 
bone reference point and poses a risk of piercing the sciatic nerve. After abandoning the location of injection into the welldeveloped gluteus muscles on the dorsal side, the von Hochstetter and Sachtleben method of injection into the gluteus medius muscle on the abdominal side was recommended for universal use [6]. In this method, the drug is administered into the muscle with less mass; furthermore, despite the use of the bone reference point, there is a high risk of selecting different sites of needle insertion in the same patient by many medical paramedics or other personnel because of differences in their hand sizes and finger length.

\section{Recommended technique for choosing a puncture site}

On the basis of the old method and the subsequent changes, a new method of locating the site of needle insertion was developed and published in 2010, which combines safety (bone reference point) and favorable conditions for absorption of the drug administered intramuscularly (the gluteus muscle on the dorsal side). Moreover, an advantage of the new method is greater comfort for the patient because in order to locate the insertion site, it is enough to bare only the upper part rather than the whole buttock, which also facilitates the paramedic's work, particularly in the case of an uncooperative patient. The patient's optimum position with the use of the new way of locating the site of needle insertion into the gluteus muscle on the dorsal side is the lateral position with a slightly bent leg at the top. The admissible positions are also the position on one's stomach with the toes pointing to the other foot and the sitting position propped on the flank, with the relaxed and slightly bent leg on the injection side. In order to determine the site of needle insertion the buttock breadth is defined by two parallel lines: the spinal line and the medial axillary line. The buttock is then vertically divided by half and the outer half is divided once again by half. From the anterior superior iliac spine, a horizontal line is drawn which, at the intersection with the vertical line defining one fourth of the outer part of the buttock, determines the safe site of injection far away from the sciatic nerve, with a simultaneous access to large mass muscle. (Figure 1a, 1b) [5].

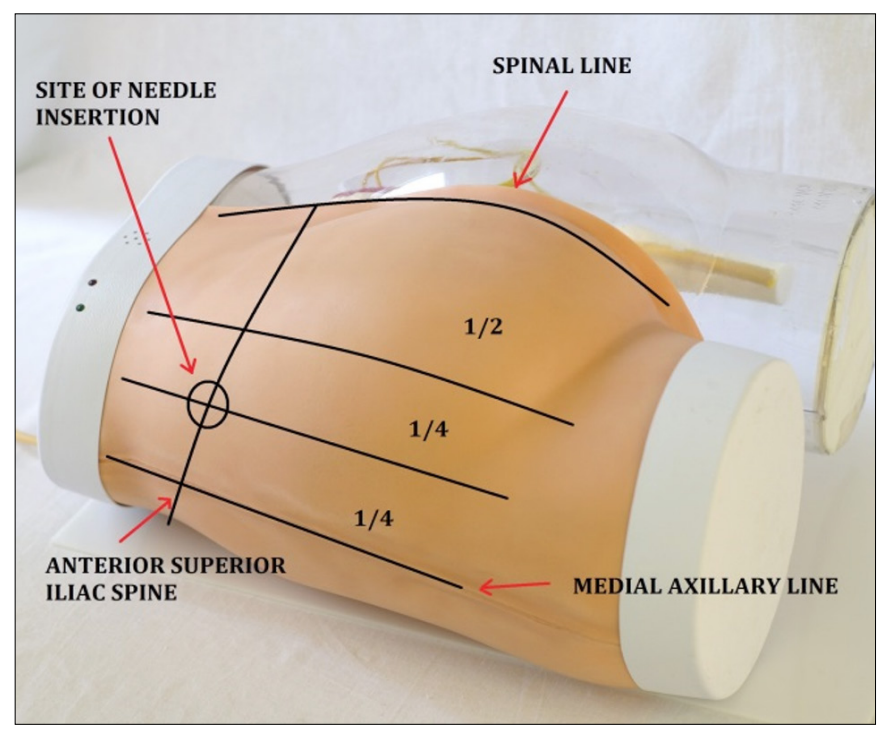

FIGURE 1A. The safe way of locating the site of needle insertion into the gluteus muscles on the dorsal site (side view)[5].

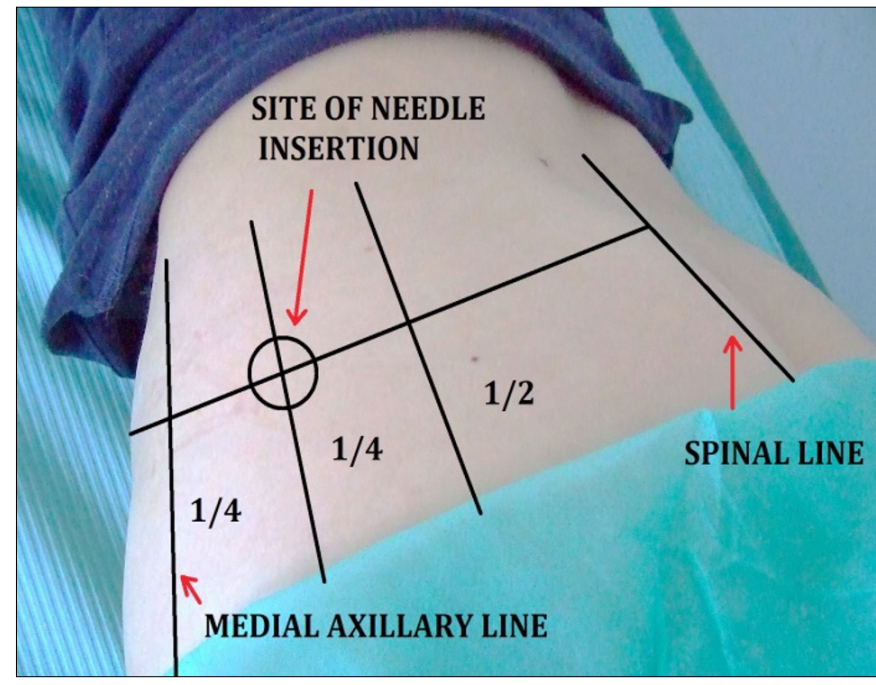

FIGURE 1B. The safe way of locating the site of needle insertion into the gluteus muscles on the dorsal side (bird's-eye view)[5].

The essence of intramuscular injection is to inject the correct drug into the muscle, observing the principles of asepsis. The correct drug is to be understood as one on whose packaging there is information indicating intramuscular administration (an isotonic drug in a watery, oily or crystalline form or in a suspension form), a drug within its expiry date, with an unchanged appearance; one that contains the correct dose and has been administered to the right patient.

The volume of the drug being administered should be adjusted to muscle mass. An adult with normal musculature can be given a maximum of $5 \mathrm{ml}$ into the gluteus muscle on the dorsal or abdominal side, as well as into the quadriceps femoris, and up to $2 \mathrm{ml}$ into the deltoid muscle. In the case of too small muscle mass, the necessity of reducing the volume of the drug administered into one site or administering it via an alternative route should be considered. In newborns and infants aged up to three months who do not have sufficiently developed muscle tissue, intramuscular injections are ruled out in order to minimize the risk of damage to muscle tissue [13].

In an intramuscular injection, the needle is inserted at an angle of $90^{\circ}$ in relation to the body surface with the skin between the thumb and index finger being simultaneously stretched to obtain the shortest route to the muscle and minimize the pain of the needle passing through the skin. The needle is inserted at a depth necessary for inserting its cutting edge into the muscle, but no deeper than $3 / 4$ of its length $[3-5,7,11]$.

A specific and absolute contraindication against administering the drug intramuscularly is centralization of circulation (shock, hypothermia) and proneness to bleeding (hemorrhagic diathesis, hemophilia, treatment with antithrombotic drugs).

A relative contraindication that necessitates the choice of an alternative site of injection or search for effective solutions is the affected tissue on the site of potential needle insertion (reddening, edema, rash, birthmark, scar, intumescence, abscess, fibrosis of subcutaneous tissue, wounds, and others), the inaccessible site (e.g. covered with a plaster jacket), lack of the patient's consent or the insufficient skill of the injector [3-5,11].

In order to prevent complications of intramuscular injections, it is necessary to:

- apply the principles of asepsis

- eliminate errors (check the drug, the doctor's order, identify the patient correctly) 
- prevent the needle from breaking (stabilize the needle properly as well as the hands of the injector, inform the patient about the moment of needle insertion, use help if it is necessary to stabilize the patient, do not introduce the needle as deep as its hub)

- administer the drug through a needle of proper length to deliver the drug to muscle tissue

- aspirate before administering the drug to prevent the Hoigne or Nicolau syndrome

- administer the drug at moderate speed

- ensure the patient's safety and the possibility of relaxing the punctured muscles

- do not combine different drugs in one syringe

- choose the site of needle insertion with a safe technique to maintain a distance from the sciatic nerve and large blood vessels

The technique of administering two drugs in one injection using the change in the direction of the needle is of the question. The justification for this contraindication is the failure to maintain the right angle in reaching the muscle [14].

The current medical reality is fairly complicated. The patient undergoes many invasive treatments, procedures, interventions using modern equipment, and therapies intended to help the patient; however, for this to happen it is necessary always and with each intervention to the patient - to be guided by the principle of Hippocrates, the father of medicine "First do no harm". These words are a manifestation of the genius of the human mind and heart, which have to be adopted as their own by all healthcare personnel so as to preserve the ethos and humanism of the profession and give the patient a sense of security in a difficult health situation.

\section{REFERENCES}

1. Rozporządzenie Ministra Zdrowia z dnia 20 kwietnia 2016 r. w sprawie medycznych czynności ratunkowych i świadczeń zdrowotnych innych niż medyczne czynności ratunkowe, które mogą być udzielane przez ratownika medycznego (Dz. U. poz. 587).

2. Rozporządzenie Ministra Zdrowia z dnia 3 lipca 2017 r. zmieniające rozporządzenie $\mathrm{W}$ sprawie medycznych czynności ratunkowych i świadczeń zdrowotnych innych niż medyczne czynności ratunkowe, które mogą być udzielane przez ratownika medycznego (Dz. U. poz.1364).

3. Ciechaniewicz W. (ed). Pielęgniarstwo. Ćwiczenia. Warszawa: Wydawnictwo Lekarskie PZWL; 2002, p. 394-5, 443-5.

4. Ciechaniewicz W. (ed). Wstrzyknięcia. Warszawa: Wydawnictwo Lekarskie PZWL; 2007, p. 109-18.

5. Dzirba A. Wstrzyknięcia domięśniowe. Warszawa: Wydawnictwo Lekarskie PZWL; 2010, p. 9-37.

6. Hildebrant N. Iniekcje, infuzje, pobieranie krwi. Wrocław: Wydawnictwo Medyczne URBAN \& PARTNER; 2001, p. 13-19, 26-36.

7. Huber A, Karasek-Kreutzinger B, Jobin-Howald U. Kompendium pielęgniarstwa. Warszawa: Wydawnictwo Lekarskie PZWL; 1995, p. $435-$ 41.

8. Jakubaszko J. (ed). Pielęgniarstwo. Wrocław: Wydawnictwo Medyczne URBAN \& PARTNER; 1997, p. 133-136.

9. Kózka M, Płaszewska-Żywko L. (eds). Procedury pielęgniarskie. Warszawa: Wydawnictwo Lekarskie PZWL; 2009, p. 577-80.

10. Ślusarska B, Zarzycka D, Zahradniczek K. (eds). Podstawy pielęgniarstwa. T. 2. Lublin: Wydawnictwo CZELEJ; 2008, p. 973-80.

11. Wołynka S. Pielęgniarstwo ogólne. Warszawa PZWL; 1981, p. 453- 61.

12. Zahradniczek K. (ed). Pielęgniarstwo. Warszawa: Wydawnictwo Lekarskie PZWL; 2005, p. 456-60.

13. Zalecenia Krajowego Konsultanta w dziedzinie pielęgniarstwa pediatrycznego 12 marca $2018 \mathrm{r}$. w sprawie podawania antybiotyków u dzieci na zlecenie lekarskie w domu chorego.

14. Opinia Konsultanta Wojewódzkiego w dziedzinie Pielęgniarstwa Rodzinnego dla województwa lubelskiego w sprawie podawania leków we wstrzyknięciach domięśniowych. In: Nasz Głos March/April 2018;34.

\section{Corresponding author}

Dr Patrycja Misztal-Okońska

Department of Emergency Medicine, Medical University of Lublin

Staszica 4-6 St., 20-081 Lublin, Poland

E-mail: patrycja.okonska@umlub.pl

tel: +48814486830 